\title{
STRATEGIJA RAZVOJA BIZNISA I
} KONKURENTNOST: STUDIJA SLUČAJA REPUBLIKE SRBIJE

\author{
STRATEGIC BUSINESS DEVELOPMENT AND \\ COMPETITIVENESS: THE CASE STUDY OF REPUBLIC OF \\ SERBIA
}

\section{Dubravka Škunca}

Fakultet za poslovno industrijski menadžment, Univerzitet „Union - Nikola Tesla“, Beograd, Srbija

(C) MESTE NGO

JEL Category: F23, L1

\section{Apstrakt}

Konkurentnost nacija je polje ekonomske teorije koje analizira sposobnost nacionalne privrede da kreira i zadrži okruženje koje dodaje vrednost preduzećima, a stanovništvu obezbeđuje prosperitet. Organizacija za ekonomsku saradnju i razvoj definiše konkurentnost kao stepen do koga, u uslovima fer tržišta i trgovine, nacionalna privreda može da proizvodi dobra i usluge koji će zadovoljiti međunarodno tržište, a istovremeno da dugoročno poveća realne prihode svojih stanovnika. Postoji izražena veza između konkurentnosti nacija i novog, globalnog svetskog poretka. Globalizacija je uklonila granice među državama i stvorila ogromno prostranstvo. Međutim, države će na tom prostoru biti vidljive samo ukoliko se nadmetanjem izbore za visoko mesto na listama konkurentnosti. Ovaj rad istražuje korelaciju između međunarodne konkurentnosti i uslova koje propisuje država, a koji određuju kako se kompanije osnivaju, organizuju, kako se njima rukovodi, kao i kakva će biti priroda rivaliteta na domaćem tržištu. Firme će biti konkurentnije u onim oblastima gde im država omogućava najbržu akumulaciju kapitala. Neophodno je da država daje kvalitetne i pravovremene informacije domaćim kompanijama. Zemlje će biti konkurentnije što je njihovo okruženje dinamičnije, jer će na taj način firme biti stimulisane da se stalno usavršavaju. Ali, to je mač sa dve oštrice. Jer, što je sredina dinamičnija, postoji veća verovatnoća da će više firmi propasti. Međutim, kompanije koje opstanu u tako

Adresa autora:

Dubravka Škunca

拝三: dubravkaskunca@hotmail.com konkurentnim i turbulentnim uslovima doživeće uspeh i na međunarodnom planu. Rezultati istraživanja sugerišu da industrijski klasteri vode povećanju produktivnosti, višem nivou inovacija i bržem razvoju novih biznisa, a da životni 
standard stanovnika određene zemlje može biti poboljšan zahvaljujući povećanju produktivnosti kao glavnog faktora međunarodne konkurentnosti. Takođe, možemo zaključiti da korupciju, kao i neefikasnu državnu birokratiju treba svesti na najmanji mogući nivo, budući da su oni glavni razlozi zbog kojih je Srbija zauzela tek 101. mesto u Izveštaju o globalnoj konkurentnosti Svetskog ekonomskog foruma za 2013/2014. godinu.

Ključne reči: konkurentnost nacija, klasteri, produktivnost, korupcija, Republika Srbija

\begin{abstract}
Competitiveness of nations is the area of economic theory which analysis the ability of national economy to create and sustain environment which add value to companies and prosperity to people. Organization for economic cooperation and development defines competitiveness as a measure of a country's ability in selling its products in international markets while at the same time raising real income of its citizens. There is a strong link between the competitiveness of nations and the new, global world order. Globalization has eliminated the boundaries between states and created a vast area. However, governments have realized that in this space they will be visible only if they compete for high rank on the lists of competitiveness. This paper explores the correlation between international competitiveness and national conditions that determine how companies are created, organized and managed, as well as the nature and extent of domestic rivalry. Companies will be more competitive in those areas where the state allows them the fastest accumulation of capital. It is necessary that state gives quality and timely information to domestic companies. Countries would be more competitive as their environment is more dynamic, because it will stimulate firms to constantly improve. But it is a two-edged sword. Because, as the environment is more dynamic, there is a greater probability that more businesses will fail. However, companies that survive in such a competitive and turbulent conditions will hit success at the international level. Research findings suggest that industry clusters lead to productivity increase, higher innovation rates and faster new business development and that standard of living of a country's population can be improved by raising productivity which represents the main factor for international competitiveness. Also, we can conclude that corruption, as well as inefficient government bureaucracy needs to be minimized because they are main reasons why Serbia is ranked 101st in Global Competitiveness Yearbook 20132014 issued by World Economic Forum.
\end{abstract}

Key words: competitiveness of nations, clusters, productivity, corruption, Republic of Serbia

\section{UVOD}

Konkurentnost je proces u kome jedan entitet teži da nadigra drugi. Bez obzira da li je entitet osoba, korporacija ili nacija, cilj je pobediti. Konkurentnost nacije je konsolidacija performansi kompanija i pojedinaca na mikro nivou - stvarnih činilaca ekonomskog rasta. (Porter, 1990) Konkurentnost analizira kako nacionalne privrede i preduzeća upravljaju svojim ukupnim kompetencijama da bi ostvarili prosperitet ili profit. Konkurentnost nacionalne privrede je polje ekonomske teorije koja analizira činjenice koje oblikuju sposobnost nacije da kreira i zadrži okruženje koje dodaje vrednost svojim preduzećima, a prosperitet ljudima. Za razumevanje pojma konkurentnosti u današnjim uslovima neophodno je razmotriti vezu između globalizacije i konkurentnosti. Globalizacija predstavlja povezivanje cele planete u jednu celinu. (Pečujlić, 2002) Međutim, postoje različita viđenja te celine. Prvo stanovište posmatra globalnost kao spontan, univerzalan $i$ integrativan proces. Globalizam podrazumeva bolje čovečanstvo i dalji napredak civilizacije. Akcenat je na većoj važnosti nacionalnih država i identiteta. Razvija se kultura koja odiše mundijalizmom i kosmopolitskim duhom. Ceo svet se integriše u jedan novi, bolji i pozitivniji mozaik, a svaki delić mozaika ima svoj zaseban identitet, ali su granice između njih izbrisane. Globalizacija je počela da se razvija još od drevnih imperija. Prema drugom stanovištu globalno društvo je u potpunosti produkt Zapadne civilizacije. Ono ukida nacionalnu državu, istovremeno se odlikujući rivalstvom i sve većim socijalnim rascepom. Nijedno stanovište ne može poreći da je globalni poredak konstantna burna integracija i povećanje međusobne zavisnosti država i ljudi na svetskom 
nivou. Novi svetski poredak zahteva državu spremnu da se bori za svoje mesto na izvanredno konkurentnom tržištu. Savremena država sa sobom nosi novu radničku klasu. Okruženje je turbulentno i zahteva stalno prilagođavanje radnika trenutnim poslovnim trendovima. Internacionalni institut za razvoj menadžmenta (IMD) iz Švajcarske i Svetski ekonomski forum objavljuju godišnje liste konkurentnosti koje neposredno rangiraju konkurentnost zemalja. Srbija se ne nalazi na listi konkurentnosti Internacionalnog instituta za razvoj menadžmenta, a razlog tome je nepostojanje institucije-partnera IMD-a. Republika Srbija se nalazi samo na listi konkurentnosti Svetskog ekonomskog foruma. (Škunca, 2012) Industrijski klasteri vode povećanju produktivnosti, višem nivou inovacija i bržem razvoju novih biznisa, a životni standard stanovnika određene zemlje može biti poboljšan zahvaljujući povećanju produktivnosti kao glavnog faktora međunarodne konkurentnosti. Korupciju, kao i neefikasnu državnu birokratiju treba svesti na najmanji mogući nivo, budući da su oni glavni razlozi zbog kojih je Srbija zauzela tek 101. mesto u Izveštaju o globalnoj konkurentnosti Svetskog ekonomskog foruma za 2013/2014. godinu.

\section{KONKURENTNOST NACIONALNIH PRIVREDA}

Komisija za industrijsku konkurentnost predsednika Amerike (US President's Commision on Industrial Competitiveness) je 1985. godine definisala konkurentnost kao stepen do kojeg nacionalna privreda, pod slobodnim i fer tržišnim uslovima, može da proizvodi robu i usluge koji zadovoljavaju probu međunarodnih tržišta, istovremeno održavajući ili povećavajući realni dohodak svojih građana. Životni standard je glavni indikator nacionalne konkurentnosti. Indeks kojim se meri životni standard je bruto domaći proizvod po stanovniku. Njime se mere dugoročni i kratkoročni porast životnog standarda, kao i nivoi standarda zasnovani na paritetima kupovne moći. (Bagarić, 2005) Produktivnost predstavlja efikasnost kojom se proizvodi roba i obezbeđuju usluge. Velikim delom je određena prethodnim investiranjem, kvalitetom i karakteristikama radne snage, tehnološkim inovacijama, kvalitetom fabrika i opreme i efektivnošću kojom se ovi faktori proizvodnje koriste. Produktivnost je istovremeno determinanta i indikator konkurentnosti nacionalne privrede. Investiranje je uslov uspešnog funkcionisanja, pa time i konkurentnosti svake ekonomije. Stvaranje bogatstva zahteva produktivnu osnovu kao temelj ekonomskog rasta. Investiranje u tehnologiju, fabrike, opremu, infrastrukturu i kadrove stvara taj temelj. Sledeći korak je poboljšanje produktivnosti. Produktivnost je refleksija efikasnosti kojom se roba i usluge proizvode. Visok nivo produktivnosti obezbeđuje značajnu prednost u odnosu na rivale. Pokušaji da se poboljša produktivnost ne treba da žrtvuju kvalitet. Kvalitet i performanse prozvoda su obavezni i odlučujući faktori sveukupne konkurentnosti. Oko 4 milijarde stanovnika sveta ima vrlo skroman životni standard. Njihova kupovna moć uopšte, pa i moć kupovine inostrane robe i usluga znatno je manja od kupovne moći stanovnika koji spadaju u bogate ili relativno bogate. Za razvijene zemlje, odnosno bogate kupce, necenovni faktori konkurentnosti su znatno važniji od visine cena. Sama činjenica da u svetskoj trgovini proizvoda i komercijalnih usluga dominiraju razvijene zemlje, govori o ogromnom značaju necenovnih faktora konkurentnosti na svetskom tržištu, kako robe, tako i komercijalnih usluga. Među tim faktorima najveći značaj imaju inovacije, tehnologija, kvalitet, dizajn i standardizacija. (Kovačević, 2002) Upravo industrijski klasteri vode povećanju produktivnosti, višem nivou inovacija i bržem razvoju novih biznisa. Prvi ekonomista koji je ukazivao na značaj nacenovnih faktora konkurentnosti, a posebno inovacija, bio je Šumpeter koji je tridesetih $i$ četrdesetih godina $X X$ veka razradio tezu da su inovacije osnovni faktor rasta i konkurentnosti. On u svom najpoznatijem radu, Kapitalizam, socijalizam i demokratija, ističe da umesto cena, dominirajući faktor konkurentnosti proizilazi iz novih proizvoda, nove tehnologije, novih izvora ponude, novog tipa organizacije $i$ ova konkurentnost obezbeđuje velike razlike $u$ troškovima proizvodnje i kvalitetu proizvoda. On je inovacioni proces podelio na invencije, inovacije i imitacije. Invencija je istraživanje i pronalaženje novih ideja i mogućnosti za kreiranje novih i poboljšanje postojećih proizvoda $i$ procesa proizvodnje u elementarnoj fazi i formi. Postoji stanovište koje zastupa tezu da je inovacija 
ekonomski, a ne tehnološki fenomen, tako da bez obzira koliko je vredna tehnološka invencija, ona ne predstavlja inovaciju ukoliko ne obezbeđuje privredni rast $\mathrm{i}$ čist profit $u$ tržišnoj privredi. Inovacioni proces i inoviranje obuhvata seriju procesa uključenih u stvaranje neke nove ideje i njenu primenu kroz novi proizvod, pri čemu to vodi dinamičnom rastu privrede i povećanju zaposlenosti, ali i stvaranju većeg profita za preduzeće koje je nosilac inovacije. Po ovom stanovištu nova ideja znači saznanje o potrebama novog klijenta ili novi način proizvodnje nekog proizvoda $\mathrm{i}$ ona se razvija tokom procesa implementiranja, komercijalizuje $u$ formi novog proizvoda koji se može ponuditi tržištu ili novog procesa proizvodnje koji donosi sniženje troškova i povećanje produktivnosti. Imitacija je preuzimanje, odnosno kopiranje inovacije od strane drugih proizvođača ili preduzeća iz sfere usluga. Za razliku od XIX veka, u toku XX veka invencije $i$ inovacije su postale sistemska $i$ svrsishodna aktivnost koja se planira, organizuje i obavlja u laboratorijama proizvodnih firmi, samostalnih instituta i univerziteta. To je posledica saznanja da u gotovo svim sektorima savremene privrede invencije i inovacije zahtevaju specijalna znanja i vrhunsku obuku, najsavremenija dostignuća, korišćenje skupih instrumenata i druge opreme, preduzimanje skupih eksperimenata, kao i interdisciplinarni rad i saradnju vrhunskih istraživača. Drugim rečima, inovacije podrazumevaju ogroman istraživačko-razvojni rad, kako na nivou firmi, tako i na nivou države. Najveći deo inovacija čine tehnološke inovacije vezane za kreiranje novih proizvoda i novih tehnologija, usavršavanje postojećih proizvoda $i$ tehnologija i osvajanje i unapređenje proizvoda i tehnologija kreiranih u inostranstvu. Tehnologija je postala dominantan faktor konkurentnosti u istraživačko-intenzivnim sektorima, kao što su elektronika, farmaceutska i hemijska industrija i mašinogradnja. (Kovačević, 2002) Postoji i niz primera kojima se dokazuje da tehnologija doprinosi povećanju konkurentnosti na svetskom tržištu i kod proizvoda iz sektora koji ne spadaju u istraživačko-intenzivne, kao što su crna metalurgija i tekstilna industrija. Poslednjih dvadesetak godina tehnologija je bitno doprinela povećanju konkurentnosti ovakvih proizvoda na svetskom tržištu. Konkurentnost zemlje u znanju se definiše kao mogućnost kreiranja nove ideje i sposobnosti da se iskoristi njena ekonomska vrednost. Pri formiranju indeksa konkurentnosti znanja koriste se pokazatelji izdataka za naučno-istraživački i razvojni rad u kompanijama, izdaci za obrazovanje i obuku kadrova i nivo razvijenosti infrastrukture za informacione tehnologije. Pri dobijanju indeksa konkurentnosti u znanju koristi se i broj zaposlenih u industriji i broj registrovanih patenata. Postoji ogroman broj elemenata kvaliteta proizvoda i usluga, kao što su trajnost, pouzdanost, produktivnost, ekonomičnost pri upotrebi, stepen zadovoljenja ergonomskih i ekoloških zahteva, usklađenost sa međunarodnim standardima, funkcionalnost, dimenzije, dizajn, izrada i pakovanje i za svaki konkretan proizvod ili uslugu ovi faktori čine njegov kvalitet. Nivo kvaliteta i napredak u kvalitetu proizvoda i usluga u najvećoj meri zavisi od sposobnosti kreiranja inovacija i od istraživačko-razvojnog rada, usmerenog na kreiranje novih kvalitetnijih proizvoda i usavršavanje postojećih domaćih $\mathrm{i}$ stranih proizvoda. Visoka korelacija između tehnoloških inovacija i konkurentnosti izvoza, velikim delom dokazuje i visoku korelaciju između napretka i nivoa kvaliteta proizvoda i usluga i rasta konkurentnosti na svetskom tržištu. Veoma dinamičan rast dohotka po glavi stanovnika u brojnim zemljama i veoma izražene strukturne promene u svetskoj trgovini, sve jača konkurencija na svetskom tržištu i niz drugih ekonomskih i neekonomskih faktora su uticali na znatno povećanje značaja kvaliteta proizvoda i usluga za plasman na svetskom tržištu, pogotovu na tržištu razvijenih zemalja. Poslednjih decenija XX veka dva elementa kvaliteta su posebno dobili na značaju kao faktori konkurentnosti na svetskom tržištu, a to su međunarodna standardizacija i dizajn. Međunarodna organizacija za standardizaciju donosi međunarodne standarde iz gotovo svih oblasti privrednih i vanprivrednih sektora, tehnologije $\mathrm{i}$ informacionih tehnologija. Njeni standardi su neobavezni. Međutim, određeni procenat njenih standarda - uglavnom onih koji se odnose na čuvanje zdravlja, bezbednost ili zaštitu životne sredine - usvojeni su u nizu zemalja kao deo njihove obavezujuće regulative. Standardizacija je postala bitan faktor međunarodne trgovine i konkurentnosti na 
svetskom tržištu, a posebno na tržištu najrazvijenijih zemalja. Uslov za prodaju niza proizvoda na tržištu Evropske unije je da su njihovi proizvođači obezbedili i stekli pravo da na njima ili njihovoj ambalaži stave znak međunarodnog kvaliteta. Ogroman broj poljoprivrednoprehrambenih proizvoda se, na primer, ne može uvoziti u čitavom nizu zemalja ako nisu ispunjeni predviđeni standardi u tim zemljama. Sve je veći broj nerazvijenih zemalja i zemalja u tranziciji koje su članice ISO i mnoge od njih uvode konkretne međunarodne standarde, tako da na tržištu tih zemalja ovi standardi postaju sve značajniji faktor konkurentnosti, kako za domaću, tako i za stranu robu i usluge. Naročito je u zemljama u razvoju i u zemljama u tranziciji, koje su privukle više stranih direktnih investicija i u kojima je formiran veliki broj filijala inostranih transnacionalnih kompanija, standardizacija kao faktor konkurentnosti znatno dobila na značaju. Takođe, i u zemljama iz ove dve grupe koje su liberalizovale uvoz robe i usluga u kojima dohodak po glavi stanovnika dinamično raste i dostigao je relativno visok nivo, standardizacija postaje sve značajniji faktor konkurentnosti. Naime, inostrane kompanije, bilo preko direktnog izvoza, bilo preko filijala i zajedničkih preduzeća lociranih u ovim zemljama nameću, i vrlo agresivno ističu da su njihovi proizvodi, njihovi tehnološki procesi i usluge zasnovani na visokim međunarodnim standardima, da su zbog toga superiorni u odnosu na konkurentske proizvode i usluge i po osnovu toga zauzimaju sve veći deo tržišta tih zemalja. Pored proizvođača finalnih proizvoda, bitno je da $i$ svi isporučioci reprodukcionih materijala i sirovina uvedu sistem menadžmenta kvalitetom, jer bez toga nije moguće ostvariti uspešne klastere preduzeća. Kvalitet dizajna je takođe vrlo važan faktor konkurentnosti na svetskom tržištu, a posebno na tržištu razvijenih zemalja. Sa rastom životnog standarda i dostizanjem njegovog visokog nivoa, sve veći broj kupaca na svetskom tržištu izuzetnu pažnju poklanja dizajnu, pa je on zaista postao moćno konkurentsko oruđe. S druge strane, zbog sve jače konkurencije na svetskom tržištu, mnoge zemlje i firme ulažu ogromne napore i sredstva kako bi preko dizajna povećale konkurentnost na svom, a posebno na svetskom tržištu. Postoji i ogroman broj drugih necenovnih faktora konkurentnosti na svetskom tržištu i tržištima pojedinih zemalja. Ugled zemlje u poslovnom svetu, na primer, može biti vrlo značajan faktor konkurentnosti njenog izvoza. Ako je zemlja pod sankcijama Ujedinjenih nacija, konkurentnost njenog izvoza se drastično smanjuje. Čak i kad nije pod sankcijama, ugled neke zemlje, najčešće zbog politike koju njeno rukovodstvo vodi, može u nekom vremenskom periodu biti vrlo nizak. $S$ druge strane, visok ugled neke zemlje u poslovnom svetu, koji se stvara preko privrednih rezultata, politike koju vodi, pa sve do sportskih dostignuća, značajno povećava startnu konkurentsku poziciju, koja u slučaju ostalih jednakih uslova, dovodi do rasta njenog izvoza. Sistem kvaliteta obrazovanja, od osnovne škole do master i doktorskih studija, direktno i indirektno utiče na konkurentnost jedne zemlje na svetskom tržištu. Jedan od idejnih tvoraca poslednjeg impresivnog rasta američke privrede Li Ajakoka ističe da se konkurentnost jedne države ne stvara na njivi i fabrici ili u laboratoriji, već u školskom razredu. Ova tvrdnja se zasniva na sve većem ubeđenju da je kvalitet ljudskog kapitala najvažniji faktor međunarodne konkurentnosti, a on se pre svega postiže kvalitetnim obrazovanjem. (Kovačević, 2002)

\section{REPUBLIKA SRBIJA NA LISTAMA KONKURENTNOSTI}

Majkl Porter, idejni tvorac metodologije merenja konkurentnosti koju koristi Svetski ekonomski forum, osmislio je 12 stubova konkurentnosti u koje spadaju institucije, infrastruktura, makroekonomsko okruženje, osnovno obrazovanje i zdravlje, visoko obrazovanje i trening, efikasnost tržišta robe, efikasnost tržišta rada, razvijenost finansijskog tržišta, tehnološka spremnost, veličina tržišta, poslovna sofisticiranost i inovacije. Navedenih 12 stubova podeljeno je u tri grupe, a to su osnovne potrebe, faktori uvećanja efikasnosti i inovativni faktori i faktori sofisticiranosti. $U$ najnovijem izveštaju, odnosno Globalnom pregledu konkurentnosti Svetskog ekonomskog foruma za 2013-2014. godinu, Srbija je svoju globalnu konkurentsku poziciju pogoršala za šest mesta - sa devedeset petog pala je na sto prvo mesto (od rangiranih 148 zemalja). Svetski ekonomski forum, odnosno njegov godišnji Izveštaj o konkurentnosti je danas prihvaćen kao osnova za analizu konkurentnosti 
nacionalnih privreda. Prema tom Izveštaju konkurentnost je skup institucija, politika, i faktora koji određuju nivo produktivnosti jedne zemlje, odnosno nivo nacionalne konkurentnosti odražava i nivo sposobnosti zemlje da svom stanovništvu pruža rastući prosperitet. Osnovne potrebe čine stubovi kao što su institucije (Srbija zauzima 126. mesto) i infrastruktura (Srbija je na 90. mestu); zatim makroekonomsko okruženje, gde Srbija zauzima 136. mesto i stub osnovnog obrazovanja i zdravlja i tu Srbija zauzima 69. mesto. Problem konkurentnosti privrede Republike Srbije je i u tome što sistem institucija ne funkcioniše. Ukupni rang Srbije u oblasti osnovnih potreba je 106. mesto. Faktore uvećanja efikasnosti čine visoko obrazovanje i obuka, efikasnost tržišta roba, efikasnost tržišta rada, razvijenost finansijskog tržišta, tehnološka spremnost i veličina tržišta. Najviši rang Srbija zauzima u oblasti tehnološke spremnosti i to 60 . mesto, a najniži u sferi efikasnosti tržišta roba, jer se nalazi na 132. mestu. Ukupni rang Srbije koji se tiče faktora uvećanja efikasnosti je 92. mesto. Inovativni faktori i faktori sofisticiranosti su poslovna sofisticiranost (Srbija je na 137. mestu) i inovacije (112. mesto). Ukupni rang Srbije u oblasti inovativnih faktora i faktora sofisticiranosti je 125. mesto (World Economic Forum, 2013). Globalni pregled konkurentnosti objavljuje i rezultate ankete koja se sprovodi svake godine među poslovnim ljudima. Od anketiranih se očekuje da ocene 16 faktora, a zatim se pravi lista najproblematičnijih faktora koji negativno utiču na konkurentnost date zemlje. Za Srbiju su dva najproblematičnija faktora korupcija i neefikasna državna administracija. Po mišljenju privrednika ova dva navedena faktora su mnogo bitnija od neadekvatno obrazovane radne snage i restriktivnih propisa radnog zakonodavstva. U nekim važnim kategorijama Srbija je na samom dnu tabela. Po usvajanju savremene tehnologije u preduzećima Srbija se nalazi tek na 137. mestu. Po mogućnostima obezbeđivanja najsavremenije tehnologije zauzimamo 118. mesto, dok smo po kvalitetu odnosa i saradnje radnika i poslodavaca na 144. mestu. U svim ovim kategorijama pozicija Srbije je znatno lošija u odnosu na opšti rang konkurentnosti. Takođe, po efikasnosti korporativnih upravnih odbora smo tek na 138. mestu, a po zaštiti manjinskih akcionara na dalekom 144. mestu. Po indikatoru oslanjanje na profesionalne menadžere Srbija se nalazi takođe vrlo nisko i to na 135. mestu. Produktivnost bitno određuje i stopu povraćaja na uložena sredstva, kao i opšti društveni ekonomski rast i razvoj. Privrednici bi zato trebalo da budu jako zainteresovani za stopu povraćaja na investicije pošto je njihov profit direktno vezan za to. Međutim, povraćaj na investicije tj. prihod, može se ostvariti, i često se ostvaruje, nezavisno od produktivnosti - namicanjem cena, netržišnim pozicioniranjem, odnosno izbegavanjem tržišta kad god i gde god je to moguće, a ne oslanjanjem na tržište da bi se do maksimuma iskoristile sopstvene ekonomske komparativne prednosti. Takvo ponašanje na kratak rok donosi korist preduzećima koja se tako ponašaju, ali na srednji i duži rok i društvo i privreda, pa čak i takvi privrednici gube. Možemo postaviti pitanja zašto se ne koristi najsavremenija tehnologija, zašto se ne zapošljavaju kadrovi koji završe fakultete i zašto smo po obuci uz rad na 140. mestu u svetu. Država svojim zakonima definiše pravila koja utiču na konkurentnost nacionalne privrede. Država i njene institucije direktno utiču na definisanje svojinskih prava gde smo tek 130 . u svetu, na zaštitu intelektualnih prava (115. mesto), na nezavisnost sudstva (124. mesto), kao i na opterećenje državnom regulativom, gde smo na 142. mestu. Država bi trebalo da implementira određene promene da bi se indikator favorizovanje u odlukama državnih službenika poboljšao (sada smo na 127. mestu). Država takođe treba da podstiče lokalnu konkurenciju, gde smo na 138. mestu, odnosno da suzbija tržišnu dominaciju i monopole. Po efikasnosti suzbijanja monopola Republika Srbija se nalazi gotovo na samom kraju liste, na 141. mestu. Veoma su dobri indikatori vezani za zdravlje i osnovno obrazovanje, međutim u ovu kategoriju ulazi i kriterijum vezan za prisutnost, odnosno odsutnost malarije, i Srbija je na 1. mestu u svetu, jer kod nas nema slučajeva malarije. Takođe, u sferi zdravlja i primarnog obrazovanja Srbija se nalazi na 11. mestu u oblasti zastupljenosti HIV virusa, ali ima i jako mali broj osoba testiranih na HIV virus. Nedovoljan pomak privrede Republike Srbije na listi konkurentnosti može se objasniti i činjenicom da država više pažnje poklanja donošenju zakona nego njihovoj primeni. Situacija 
bi se svakako brže menjala da se doneti zakoni striktno poštuju. Po opterećenju državnom regulativom Srbija je na 142. mestu. Treba ukinuti određene propise, ali i smanjiti period čekanja na dozvole za izgradnju. Kako je među investitorima veliki broj i onih iz inostranstva, to će na indirektan način povećati konkurentnost privrede. $U$ domen državne uprave spada i suzbijanje organizovanog i privrednog kriminala, kao i korupcije, što svakako može bitno povećati konkurentnost privrede. Podizanju konkurentnosti zemlje značajno mogu doprineti i obrazovne institucije, a pre svega visoko obrazovanje. Po kvalitetu osnovnog obrazovanja nalazimo se na 81. mestu, po srednjem obrazovanju na 62. mestu, a po visokom obrazovanju u sferi škola menadžmenta tek na 114. mestu. Po kapacitetu da zadrži talente Republika Srbija je na 146. mestu, što znači da se na tom polju gotovo ništa nije uradilo poslednjih godina (World Economic Forum, 2013).

Internacionalni institut za razvoj menadžmenta iz Švajcarske u svom Svetskom godišnjaku konkurentnosti koristi četiri osnovne determinante konkurentnosti, i to performanse privrede, efikasnost državne uprave, efikasnost poslovanja i infrastrukturu. Svaka od navedene četiri determinante je podeljena na pet oblasti. Determinantu vezanu za performanse privrede čine domaća privreda, međunarodna trgovina, međunarodne investicije, zaposlenost $i$ cene. Efikasnost državne uprave u sebi sadrži javne finansije, poresku politiku, institucionalni okvir, poslovno zakonodavstvo i socijalni sistem. Efikasnost poslovanja se sastoji od produktivnosti, tržišta rada, finansija, menadžment prakse i stanovišta i vrednosti. Sastavni delovi determinante infrastruktura su osnovna infrastruktura, tehnološka infrastruktura, naučna infrastruktura, zdravstvo i životna sredina i obrazovanje. (Garelli, 2006)

\section{STRATEGIJA RAZVOJA BIZNISA}

Osim Svetskog ekonomskog foruma i Internacionalnog instituta za razvoj menadžmenta i Međunarodna banka za obnovu i razvoj sa Svetskom bankom učestvuje u izdavanju izveštaja Poslovanje koji posredno rangira konkurentnost određenih zemalja. Poslovanje u 2014. godini prezentuje kvantitativne indikatore poslovne regulative i zaštitu vlasničkih prava. Ove godine je rangirano 189 zemalja, a Singapur je na vrhu liste. Srbija je rangirana kao 93. zemlja u izveštaju Poslovanje u 2014. godini. U prošlogodišnjem izveštaju Srbija je bila na 86. mestu. Položaj Srbije je ocenjen u oblasti pokretanja poslovanja, dobijanja dozvola, zapošljavanja radnika, registracije vlasništva, dobijanja kredita, zaštite investitora, plaćanja poreza, prekogranične trgovine, izvršenja ugovora i zatvaranja poslovanja. Prema godišnjaku Poslovanje u 2014. godini Srbija nije imala reforme u ovim oblastima. Potrebno je 6 procedura i 11,5 dana da bi se započeo biznis u Srbiji. Srbija je rangirana kao 45 . u domenu pokretanja poslovanja. U Poslovanju u 2013. godini je $u$ istoj oblasti zauzimala 38. mesto. Srbija je vrlo nisko rangirana u oblasti dobijanja dozvola. Nalazi se na 182. mestu. Postoji 18 procedura, a procenjeno vreme za izgradnju skladišta u Srbiji je 269 dana. U Poslovanju u 2013. godini Srbija je takođe zauzela 182. mesto u oblasti dobijanja dozvola. Srbija je na 85. mestu u oblasti dobijanja priključka za električnu energiju. Potrebno je 4 procedure i 131 dan. U Poslovanju u 2013. godini Srbija je zauzimala 81. mesto u ovoj oblasti. Kod registracije vlasništva Srbija je rangirana kao 44. zemlja, potrebno je 6 procedura i košta $2,8 \%$ od vrednosti poseda. U Poslovanju u 2013. godini Srbija je bila na 41 . mestu u oblasti registracije vlasništva. U oblasti dobijanja kredita Srbija zauzima 42. mesto. Indeks snage zakonskih prava (0-10) je 7, a indeks dubine informacija o kreditima (0-6) je 5. U Poslovanju u 2013. godini Srbija je zauzimala 40. mesto u oblasti dobijanja kredita. Srbija zauzima 80. mesto u oblasti zaštite investitora. Indeks odgovornosti direktora (0-10) je 6 , indeks zaštite akcionara $(0-10)$ je 3 , a indeks zaštite investitora (0-10) je 5,3. U Poslovanju u 2013. godini Srbija je takođe bila rangirana kao 80 . u oblasti zaštite investitora. Kada investitori osećaju da su njihova imovinska prava zaštićena onda su performanse institucija superiorne. Bitno je da se investitori osećaju sigurno, bez obzira na koji način je ova sigurnost ostvarena. Da bi bio efektivan, formalni zakonski režim koji štiti prava investitora zahteva nekorumpirano, nezavisno sudstvo. Stvaranje takvog sudstva je teško sa niskim nivoima prihoda i iziskuje vreme. Siromašna zemlja koja može da ojača imovinska prava preduzetnika $i$ investitora će verovatno iskusiti dugotrajno povećanje svog 
produktivnog kapaciteta. Nacionalnim ekonomijama ne treba ekstenzivan set institucionalnih reformi da bi počele da rastu. Kada je privreda dosta ispod svog potencijalnog konstantnog i stabilnog nivoa prihoda, čak $i$ skromni pomaci u pravom smeru mogu dovesti do velikog rasta. Važno je da se privrede u tranziciji integrišu u svetsku privredu povećanjem tokova stranih direktnih investicija. Glavni razlog je to što strane direktne investicije podižu produktivnost kompanija koje su ranije bile u državnom vlasništvu. Bruto domaći proizvod i jedinični troškovi rada su značajne determinante stranih direktnih investicija i ovo indicira da privrede koje žele da ohrabre priliv stranih direktnih investicija treba da uvedu režim politike koji će dovesti do visokog i održivog ekonomskog rasta koji će biti kombinovan sa nagomilavanjem niskih nadnica. Takođe, postoji jasan dokaz da se strane direktne investicije mogu povećati snažnim domaćim institucijama, sa poštovanjem imovinskih prava, strukture tržišta kapitala $i$ korporativne vlade. Nacionalne privrede koje žele da povećaju priliv stranih direktnih investicija u Jugoistočnu Evropu treba da poboljšaju svoj institucionalni razvoj. Takođe, treba da uvedu politiku koja će kreirati okruženje pogodno za strane investitore, uključujući $i$ to da ovim investitorima otvore privatizaciju. Srbija zauzima 161. mesto u oblasti plaćanja poreza. Broj plaćanja godišnje iznosi 66, potrebno vreme je 279 sati godišnje. U Poslovanju u 2013. godini Srbija je bila na 157. mestu. Srbija je na 98. mestu u oblasti prekogranične trgovine. Broj dokumenata potrebnih za izvoz je 6, a vreme izvoza je 12 dana. Broj dokumenata potrebnih za uvoz je 7, vreme uvoza je 15 dana. U Poslovanju $u$ 2013. godini Srbija je bila na 102. mestu u oblasti prekogranične trgovine. Srbija je na 116. mestu u oblasti izvršenja ugovora. Potrebno je 36 procedura, 635 dana, a trošak je $34 \%$ od potraživanja. U Poslovanju u 2013. godini Srbija je bila na 100. mestu u ovoj oblasti. Srbija je na 103. mestu u oblasti zatvaranja poslovanja. Potrebno je 2 godine, a stopa povraćaja je 29 centi na jedan dolar. U Poslovanju u 2013. godini Srbija je zauzimala 104. mesto u oblasti zatvaranja poslovanja. (World Bank, 2013) Republika Srbija je pogoršala svoj položaj u odnosu na prethodnu godinu u većini ocenjenih oblasti $i$ to $u$ okviru pokretanja poslovanja, dobijanja priključka za električnu energiju, registracije vlasništva, dobijanja kredita, plaćanja poreza i izvršenja ugovora. Strategiju razvoja biznisa bi stoga trebalo usmeriti ka unapređenju ovih rezultata.

\section{ZAKLJUČAK}

Konkurentnost nacija je polje ekonomske teorije koje analizira sposobnost nacionalne privrede da kreira i zadrži okruženje koje dodaje vrednost preduzećima, a stanovništvu obezbeđuje prosperitet. Organizacija za ekonomsku saradnju i razvoj definiše konkurentnost kao stepen do koga, u uslovima fer tržišta i trgovine, nacionalna privreda može da proizvodi dobra i usluge koji će zadovoljiti međunarodno tržište, a istovremeno da dugoročno poveća realne prihode svojih stanovnika. Postoji izražena veza između konkurentnosti nacija i novog, globalnog svetskog poretka. Firme će biti konkurentnije u onim oblastima gde im država omogućava najbržu akumulaciju kapitala. Neophodno je da država daje kvalitetne i pravovremene informacije domaćim kompanijama. Zemlje će biti konkurentnije što je njihovo okruženje dinamičnije, jer će na taj način firme biti stimulisane da se stalno usavršavaju. Ali, to je mač sa dve oštrice. Jer, što je sredina dinamičnija, postoji veća verovatnoća da će više firmi propasti. Međutim, kompanije koje opstanu u tako konkurentnim i turbulentnim uslovima doživeće uspeh i na međunarodnom planu. Rezultati istraživanja sugerišu da industrijski klasteri vode povećanju produktivnosti, višem nivou inovacija i bržem razvoju novih biznisa, a da životni standard stanovnika određene zemlje može biti poboljšan zahvaljujući povećanju produktivnosti kao glavnog faktora međunarodne konkurentnosti. Globalni pregled konkurentnosti objavljuje i rezultate ankete koja se sprovodi svake godine među poslovnim ljudima. Od anketiranih se očekuje da ocene određene faktore, a zatim se pravi lista najproblematičnijih faktora koji negativno utiču na konkurentnost date zemlje. Za Srbiju su to korupcija i neefikasna državna administracija. Po mišljenju privrednika oni su mnogo bitniji od neadekvatno obrazovane radne snage i restriktivnih propisa radnog zakonodavstva. Tako da možemo zaključiti da korupciju, kao i neefikasnu državnu birokratiju treba svesti na najmanji mogući nivo, budući da su oni glavni 
razlozi zbog kojih je Srbija zauzela tek 101. mesto u Izveštaju o globalnoj konkurentnosti Svetskog ekonomskog foruma za 2013/2014. godinu. Međunarodna banka za obnovu i razvoj sa Svetskom bankom učestvuje u izdavanju izveštaja Poslovanje koji posredno rangira konkurentnost određenih zemalja. Poslovanje u 2014. godini prezentuje kvantitativne indikatore poslovne regulative i zaštitu vlasničkih prava. Ove godine je rangirano 189 zemalja, a Singapur je na vrhu liste. Republika Srbija je pogoršala svoj položaj u odnosu na prethodnu godinu u većini ocenjenih oblasti $\mathrm{i}$ to $u$ okviru pokretanja poslovanja, dobijanja priključka za električnu energiju, registracije vlasništva, dobijanja kredita, plaćanja poreza i izvršenja ugovora. Strategiju razvoja biznisa bi stoga trebalo usmeriti ka unapređenju ovih rezultata.

\section{CITIRANI RADOVI}

Bagarić, I. (2005). Tehnološki menadžment. Beograd: Fakultet za preduzetni menadžment.

Garelli, S. (2006). Competitiveness of Nations: The Fundamentals. Laussane: IMD.

Kovačević, M. 2002. Međunarodna trgovina. Beograd: Ekonomski fakultet.

Pečujlić, M. (2002). Globalizacija - dva lika sveta. Beograd: Gutembergova galaksija.

Porter, M. (1990). The Competitive Advantage of Nations. New York: Macmillan.

Škunca, D. (2012). Operativni i strategijski menadžment. Beograd: Calibris.

World Bank. (2013). Doing Business 2014 Serbia. Washington: WB.

World Economic Forum. (2013). Global Competitiveness Yearbook 2013-2014. Geneva: WEF.

Datum prve prijave:

02.04.2014.

Datum prijema korigovanog članka: $\quad 08.04 .2015$.

Datum prihvatanja članka: $\quad 26.04 .2015$

\section{Kako citirati ovaj rad? / How to cite this article?}

Style - APA Sixth Edition:

Škunca, D. (2015, jul 15). Strategija razvoja biznisa i konkurentnost: studija slučaja Republike Srbije. (Z. Čekerevac, Ed.) FBIM Transactions, 3(2), 116-124. doi:10.12709/fbim.03.03.02.14

Style - Chicago Sixteenth Edition:

Škunca, Dubravka. 2015. "Strategija razvoja biznisa i konkurentnost: studija slučaja Republike Srbije." Edited by Zoran Čekerevac. FBIM Transactions (MESTE) 3 (2): 116-124. doi:10.12709/fbim.03.03.02.14.

Style - GOST Name Sort:

Škunca Dubravka Strategija razvoja biznisa i konkurentnost: studija slučaja Republike Srbije [Journal] // FBIM Transactions / ed. Čekerevac Zoran. - Beograd : MESTE, jul 15, 2015. - 2 : Vol. 3. - pp. 116-124

Style - Harvard Anglia:

Škunca, D., 2015. Strategija razvoja biznisa i konkurentnost: studija slučaja Republike Srbije. FBIM Transactions, 15 jul, 3(2), pp. 116-124.

Style - ISO 690 Numerical Reference:

Strategija razvoja biznisa i konkurentnost: studija slučaja Republike Srbije. Škunca, Dubravka. [ed.] Zoran Čekerevac. 2, Beograd : MESTE, jul 15, 2015, FBIM Transactions, Vol. 3, pp. 116-124. 